July 2006

\title{
The US Investigation into the Darfur Crisis and the US Government's Determination of Genocide
}

Samuel Totten

Follow this and additional works at: https://digitalcommons.usf.edu/gsp

\section{Recommended Citation}

Totten, Samuel (2006) "The US Investigation into the Darfur Crisis and the US Government's Determination of Genocide," Genocide Studies and Prevention: An International Journal: Vol. 1: Iss. 1: Article 9.

Available at: https://digitalcommons.usf.edu/gsp/vol1/iss1/9

This Articles is brought to you for free and open access by the Open Access Journals at Digital Commons @ University of South Florida. It has been accepted for inclusion in Genocide Studies and Prevention: An International Journal by an authorized editor of Digital Commons @ University of South Florida. For more information, please contact digitalcommons@usf.edu. 


\title{
The US Investigation into the Darfur Crisis and the US Government's Determination of Genocide
}

\author{
Samuel Totten \\ University of Arkansas, Fayetteville
}

\begin{abstract}
This article examines the genesis and implementation of the Atrocities Documentation Project initiated by the US State Department as well as the US government's determination that genocide had been perpetrated in Darfur, Sudan, between late 2003 and August 2004. In doing so, the author considers and analyzes the rationale for the investigation and the reasoning for the genocide determination, as given by various US officials. He also delineates and discusses the perceptions of various scholars vis-à-vis the same issues, noting that many of the latter suspect there were ulterior motives behind the genesis and implementation of the investigation as well as the genocide determination. Finally, the author discusses the positive aspects of the investigation and the potential negative ramifications of the genocide determination.
\end{abstract}

\section{Introduction}

In July and August 2004, the US Department of State sponsored a field investigation, the Darfur Atrocities Documentation Project (ADP), whose express purpose was to ascertain whether genocide had been and/or continued to be perpetrated in Darfur. By that point, the Darfur crisis had been declared "the worst humanitarian disaster in the world" by Jan Egeland, the UN under secretary for humanitarian affairs; ${ }^{1}$ the United States Holocaust Memorial Museum's Committee on Conscience had issued a genocide warning vis-à-vis the killings and death in Darfur; and both the US House of Representatives and US Senate had declared the situation to be a case of genocide.

Following an analysis of the data collected by the Darfur Atrocities Documentation Team (ADT), Secretary of State Colin Powell declared, on 9 September 2004, in a statement to the US Senate Foreign Relations Committee, that genocide had been perpetrated in Darfur.

In the year and a half since the investigation and subsequent declaration by Powell, heated debate has erupted over the true motives and value of the ADP as well as over the validity of the genocide determination. Some have asserted that while crimes against humanity have been perpetrated in Darfur, genocide has not. What follows is a discussion of the stated purpose, methodology, and findings of the ADP, as well as the debate over the motives behind the project and the determination of genocide by the US government.

\section{Purpose, Location, Methodology}

As noted above, during the late summer of 2004, the US Department of State undertook an investigation to assess whether government of Sudan (GoS) troops and/

Samuel Totten, "The US Investigation into the Darfur Crisis and the US Government's Determination of Genocide." Genocide Studies and Prevention 1, 1 (July 2006): 57-78. (C) 2006 from Genocide in Darfur: Investigation into Atrocities in the Sudan edited by Samuel Totten and Eric Markusen. Reproduced by permission of Routledge/Taylor \& Francis Group, LLC. 
or the Janjaweed (Arab militia) had committed genocide against the black African population in Darfur. As Stephen Kostas notes,

By all accounts, Andrew Natsios' frequent warnings of a growing humanitarian crisis in Darfur first alerted the US Department of State to the gravity of the situation there. Natsios, head of the United States Agency for International Development (USAID), made nine trips to Sudan between late 2003 and spring 2004 and repeatedly warned key officials at the State Department that conditions were grave and deteriorating. ${ }^{2}$

Continuing, Kostas reports,

During early 2004, [Lorne] Craner, Assistant Secretary for the State Department's Bureau of Democracy, held regular intelligence briefs with the Bureau of Intelligence and Research (INR) and the Central Intelligence Agency (CIA). [Pierre-Richard] Prosper [then US ambassador-at-large for war crimes, who had previously served as the prosecutor for the International Criminal Tribunal for Rwanda (ICTR) case against Jean-Paul Akayesu and obtained the first conviction for genocide in an international court] recalls that "as we moved into the spring of 2004, it became a little clearer, at least from the information that was emerging from our people as well as NGOs [non-governmental organizations], that there was a deliberate targeting and killing of the African population."

Significantly, the ADP was the first official investigation by one sovereign nation (the United States) into the internal strife of another sovereign nation (Sudan) for the express purpose of ascertaining whether genocide had been perpetrated or not. ${ }^{4}$ Under the auspices of the US Department of State's Bureau of Democracy, Human Rights and Labor (DRL), the Coalition for International Justice (CIJ), an NGO, was hired to recruit the investigators and to coordinate the investigation on the ground. Ultimately, twenty-four investigators from around the world formed the ADT. The areas of expertise and backgrounds of these investigators were eclectic; the investigators included, for example, an expert in the field of sex crimes and international law; a prosecutor for the US Justice Department (who had also served as a prosecutor for the ICTR); a New York City district attorney (who had worked as an investigator with the International Criminal Tribunal for the former Yugoslavia [ICTY]); two experts on genocide; and a detective from London who had served as an investigator with the ICTY.

Upon their arrival in Abeche, a desert town in the far reaches of eastern Chad, the investigators were briefed by both CIJ and USAID personnel on the then current situation in Darfur and the status of the refugee camps in Chad. Additionally, they were given several hours of training. The US State Department's Bureau of Intelligence and Research (INR) provided a detailed discussion of the research methodology and questionnaire devised for the investigation, emphasizing throughout the significance of conducting a systematic study with a random selection of respondents. The training also included a tutorial by a female police officer from the United States (who had also worked as an investigator with the ICTY) on interviewing victims of sexual assault. As each investigator would have his or her own interpreter who spoke Arabic, English, and one or more tribal languages, a session on working with interpreters was provided, conducted by a professor of linguistics, an expert on translation and working with translators, from the University of Stockholm.

Following the training session, teams of investigators were dispersed to informal settlements and UNHCR refugee camps lining the Chad side of the Chad/Sudan border which housed black African refugees forced from their villages in Darfur by GoS troops and/or the Janjaweed. As noted in the State Department's report on the ADP, 
"a plurality of the respondents were ethnic Zaghawa (46 percent), with smaller numbers belonging to the Fur ( 8 percent) and Massalit (30 percent) ethnic groups."5

Once in the field and ready to conduct interviews, each investigator and translator selected a section of the camp and counted off every tenth tent. If more than one adult (eighteen years of age or older) was present, a method of randomly selecting the interviewee was used and the person selected was asked if he or she was willing to be interviewed. (Few people declined to be interviewed, and when they did it was generally due to being extremely, if not gravely, ill or when engaged in work that had to be completed. In such a situation, the interviewer and interpreter moved on to the next occupied tent and the process of selection was repeated.) Once a person agreed to be interviewed, the rest of the people in the immediate area were politely asked to leave until the interview had been completed. This precaution was taken to enable respondents to answer the interview questions as honestly and openly as possible, without pressure or interference from family members or others.

All investigators used the eight-page Darfur Refugees Questionnaire, developed in Washington, DC, via a collaborative effort involving members of various nongovernmental organizations (including the CIJ), the American Bar Association, and staff from the State Department. ${ }^{6}$

Initially, the investigator asked his or her interpreter to introduce himself (the translator), then the investigator. Then, through the interpreter, the investigator delineated the purpose and focus of the interview. The interviewee was informed that the investigator was there to speak with him or her about his or her experience in the Darfur region of Sudan and that his or her name, identity, and responses would remain confidential. The investigator also informed the interviewee that participation in the project did not, in any way, guarantee compensation for that which had been stolen from him or her, nor did it guarantee that he or she would be asked to press charges against an alleged perpetrator or to testify at any future trial(s). Finally, each interviewee was informed that he or she should only agree to be interviewed if he or she truly wanted to be, as participation was totally voluntary and there would be no repercussions for choosing not to participate.

The interviewer began by seeking such information as the name, age, ethnic group, and years of schooling of the respondent. Subsequently, interviewees were asked to locate, on a series of maps provided for the investigators by the State Department, the town, village, or settlement from which they had been forced. Next, the interviewees were asked about when and why they had left their homes; if they had been harmed (and, if so, how); if other members of their family or their village had been harmed or killed (and, if so, who and how); if any property had been stolen from them or destroyed (and, if so, exactly how many cows, camels, goats, donkeys, chickens, bags of grain and seed, etc.); if their abode and/or village/settlement had been destroyed, partially or completely; if specific groups of people had been singled out for denunciation and/or brutality (and, if so, who and in what way(s)); if any members of their immediate family, extended family, and/or fellow villagers perished on the way to the refugee camp or settlement in which they were now residing in Chad (and, if so, who and how); why they thought they had been attacked and forced from their homes; and if, on the journey to Chad, they had witnessed or heard about other attacks on people and villages.

The interviews lasted between forty-five minutes and two hours; the average was about one hour. During the course of each interview, the investigator asked follow-up questions in order to have the respondents clarify and elaborate on points and to move 
from the general to the specific (e.g., if four attackers entered a home, were they members of the GoS and/or Janjaweed? What were the attackers wearing, and did they have any particular insignia on their uniforms or any noticeable marks, such as tattoos, scars, or disfigurements, that might help to identify them later?).

At the conclusion of each day, the investigators completed a one-page "preliminary atrocity field coding sheet" that included some thirty-six items or "event codes" (e.g., witnessed an immediate family member being killed; had been wounded; heard any racial epithets, and if so, what they were; had livestock stolen from him/her, and, if so, what kind and how many of each; witnessed aerial bombing; experienced destruction of personal property, and, if so, what; experienced the looting of personal property, and, if so, what; was personally raped; witnessed others being raped; witnessed a shooting in home village). Additionally, there were about twelve "perpetrators codes" (e.g., GoS troops, Janjaweed, other).

\section{Findings}

Ultimately, the State Department statistically analyzed 1,136 interviews conducted during the month-long ADP. Following the compilation and analysis of the survey data, ${ }^{7}$ State's Bureau of Intelligence and Research reported that "analysis of the refugee interviews points to a pattern of abuse against members of Darfur's non-Arab communities." More specifically, the interviewees reported personally witnessing or experiencing the following: killing of family member (61\%); killing of non-family member (67\%); shooting (44\%); death from displacement (28\%); abduction (25\%); beating (21\%); rape (16\%); hearing racial epithets $(33 \%)$; village destruction (81\%); theft of livestock (89\%); aerial bombing (67\%); destruction of personal property $(55 \%)$; and looting of personal property $(47 \%) .^{9}$

Significantly, the State Department report notes that "numerous credible reports corroborate the use of racial and ethnic epithets by both the Jingaweit and GOS military personnel: 'Kill the slaves! Kill the slaves!'; and 'We have orders to kill all the blacks' are common." 10

With respect to those who carried out the attacks against the black Africans and their villages, the refugees' responses indicated the following: "both the Janjaweed and the GOS military (48\%); the GOS alone (26\%); the Janjaweed alone (14\%) and unknown $(12 \%) . " 11$

\section{The Factors Resulting in the Genocide Finding}

Once the study was completed, the findings and analysis were turned over to US Ambassador-at-Large for War Crimes Pierre-Richard Prosper and US Secretary of State Colin Powell. Kostas, who interviewed Prosper in order to ascertain how the United States arrived at its "genocide determination," reports that "Craner and Prosper presented the State Department's approach as dispassionate and clinical. The purpose was 'to make a pure decision'-a 'clean legal and factual analysis' free of policy considerations-[... and in doing so they] 'analyzed the facts with the breadth of the law in mind-meaning, genocide, crimes against humanity, war crimes...". ${ }^{12}$

Through a series of wide-ranging telephone conversations and meetings (between Powell and Prosper and between Powell and various assistant secretaries within the State Department) in which the participants compared and contrasted the findings of the ADP with the wording in the UN Convention on the Prevention and Punishment of the Crime of Genocide (UNCG), it was gradually determined that genocide had been, and possibly continued to be, perpetrated in Darfur. 
In speaking with Kostas and Eric Markusen during the course of a telephone interview, Prosper noted that he and Powell had had a long and detailed discussion regarding the important but always sticky issue of "intent" (i.e., the intent of the perpetrators). Among the issues they discussed were "how they [the GoS] created these militias [the Janjaweed]; how they [the GoS] had the ability to rein them [the militias] in and then did not; how they [the GoS troops] acted in concert with the Janjaweed... in attacking these [black African] villages...the aerial bombardment and then Janjaweed would come in; and then the fact that the government of Sudan would block humanitarian assistance to people in need."13 The aforementioned actions (and, in certain cases, failures to act) led the State Department to infer genocidal intent.

Prosper also spelled out the factors State Department officials considered in coming to their determination of genocide, among the most significant of which were the following:

- the villages of the black Africans were attacked and destroyed, while nearby Arab villages were not;

- a large number of men were killed, while a large number of women were raped;

- the means to existence, such as livestock and water, were, respectively, killed and polluted; and

- the GoS prevented both medical care (and medicine) as well as humanitarian assistance from being delivered to the internally displaced persons camps, where people were dying from a lack of food, water, and medical attention. ${ }^{14}$

Ultimately, Powell, Prosper, and the other State Department personnel involved in the determination "concluded that there was a deliberate targeting of the groups with the intent to destroy." 15 Speaking about the latter, Prosper stated that while examining and discussing the concepts of unlawful killing and the causing of serious bodily and mental harm, any of which constitutes an act of genocide under the UNCG,

the real one that got us... was the deliberate infliction of conditions of life calculated to destroy the group in whole, or in part. ... [With respect to the situation in the IDP camps, Prosper and Powell could not find any] logical explanation for why the Sudan government was preventing humanitarian assistance and medicine [into the camps] other than to destroy the group. ${ }^{16}$

Kostas notes that "the government of Sudan was seen as offering unbelievable excuses, leading Powell to conclude that there was a clearly intentional effort to destroy the people in the camps who were known to be almost exclusively black African."17

Finally, and tellingly,

Prosper's experience as a prosecutor supported his understanding that genocidal intent could be inferred from the evidence as well as proved by express statements. As Prosper explains, Powell and he asked each other if the government of Sudan was not committing genocide then "What else are they trying to do?" "What else could their intent be but to destroy this group?" First, Powell and Prosper looked at the coordination and collaboration between the government of Sudan and the Jinjaweid. Then, Powell and Prosper examined how the government acted once they were shown to have knowledge of the perpetrators of violence, the targeting of black African tribes, and the scale of human destruction in Darfur. This part was most convincing: The government of Sudan "had knowledge across the board. Let's pretend that it wasn't coordinated. They knew what was going on and not only did they do nothing to stop it, they intentionally obstructed assistance that would have bettered the situation. So when you have knowledge, you take no steps to stop it, and then when people are trying 
to help you block the assistance, what else could you want other than for these people to die or to be destroyed?"18

On 9 September 2004, in testimony before the US Senate Foreign Relations Committee, Secretary of State Colin Powell stated that, "based on a consistent and widespread pattern of atrocities (killings, rapes, the burning of villages) committed by the Janjaweed and government forces against non-Arab villagers," the State Department had concluded that "genocide has been committed in Darfur and that the Government of Sudan and the Janjaweed bear responsibility-and genocide may still be occurring." 19 Continuing, Powell stated that

- the United States was continuing to press the GoS to rein in the Janjaweed and that the GoS needed to "stop being complicit in such raids"; ${ }^{20}$

- the United States continued to strongly support the work of the AU monitoring mission in Darfur, and, in fact, "initiated the Mission through base camp set-up and logistics support by a private contractor"; ${ }^{21}$ and

- the United States had also called for an "expanded AU mission in Darfur through the provision of additional observers and protection forces" and "identified $\$ 20.5$ million in FY04 funds for initial support of this expanded mission." 22

Then, acting under Article VIII of the UNCG, ${ }^{23}$ Powell reported that the United States was calling on the United Nations to initiate a full investigation into the situation in Darfur. In doing so, he said, "We believe in order to confirm the true nature, scope and totality of the crimes our evidence reveals, a full-blown and unfettered investigation needs to occur."24

Finally, Powell concluded his statement with these words:

Mr. Chairman, some seem to have been waiting for this determination of genocide to take action. In fact, however, no new action is dictated by this determination (emphasis added). We have been doing everything we can to get the Sudanese government to act responsibly. So, let us not be preoccupied with this designation of genocide. These people are in desperate need and we must help them. ${ }^{25}$

\section{Strengths and Limitations of the Investigation, the Genocide Finding, and Action Based upon the Genocide Finding}

The strengths of the ADP were many. More specifically, a methodologically sound study resulted from the thought, effort, and expertise put into the development of the questionnaire and the way the investigation was carried out. As part of the methodology, every one of the twenty-four investigators asked the same set of questions listed on the questionnaire and documented the findings using the same coding methods. The number of interviews conducted was large enough to result in statistically significant findings. Also, "the final data set used for the Documenting Atrocities in Darfur report represented three successive waves of data entry." ${ }^{26}$ More specifically, as Jonathan Howard, an analyst with the US Department of State's Office of Research, reports,

As successive teams of interviewers rotated through Chad, the Office of Research hired an international public opinion research company to create a data set from the remaining questionnaires. [T] he company's team of professional coders read each questionnaire thoroughly, verifying and correcting if necessary the interviewer's field codes. In all three rounds of data entry, a fifth of the questionnaires were randomly selected and recorded by an additional analyst to ensure accuracy in the coding process. 
Each questionnaire's demographic information, event codes and attendant information were entered into the data set. Every questionnaire was entered by two different data entry specialists, or double-punched, to verify that the correct information had been entered. Once the two data entry specialists separately entered the data from a questionnaire, a computer compared the two and flagged any discrepancies.

From the final data set, two databases were created. The first was the respondent database, in which each line of data represents an individual refugee with all related demographics and event codes for that refugee. 1,136 refugees are represented in the refugee database. The respondent data set was used to generate the atrocity percentages in the final report...

Because each respondent may have experienced the same event multiple timesnumerous refugees had experienced several attacks during their journey to Chadduring the analysis stage it was necessary to write a syntax to prevent the statistical software from counting multiple events towards the total for the survey population.... A second event database was also created in which the multiple events from each refugee's story were separated so that each line of data in the event database reported a single event. 10,304 events are represented in the event database.... From the outset, the team decided to adopt a conservative approach to reporting the data collected during the documentation mission. To this end, during all three stages of data entry, events were coded as either eyewitness or hearsay. Eyewitness events were those reported to have been directly witnessed by the respondent, while hearsay events took place outside the respondent's presence. The atrocity statistics eventually reported reflected only events reported as eyewitnessed by the refugees. ${ }^{27}$

The efforts of the State Department's people on the ground in Chad and those involved in the analysis of the data were seemingly impeccable. Indeed, State's personnel were serious, hardworking, dedicated, and demanding. From the outset, they seemed determined to collect and analyze the data in the most methodologically sound and accurate manner possible. Furthermore, the study resulted in findings that are statistically significant. $^{28}$

Be that as it may, the investigation had certain weaknesses and limitations. First, the most obvious limitation is that the investigation was conducted solely in Chad, rather than Darfur and the refugee camps in Chad. Had the ADP been given access to both those black Africans in IDP camps in Darfur and those who remained in any villages not destroyed (and, for that matter, to those Arab villagers who were not attacked but may have witnessed the attacks on the black Africans), the data would have been much richer. Entry into Darfur for the purpose of an investigation was not, it seemed, an option-or, at least, not one that the US government wanted to pursue at the cost of either totally alienating the Sudanese government or being rebuffed. Second, the respondent pool was largely limited to refugees from the westernmost states of Darfur, as well as those who, for the most part, had the shortest distance to travel to Chad. Again, the data would have been richer had the investigators been able to interview a wider swath of the black African population in Darfur. Third, as the interviews were being conducted in the first two weeks of the ADP, various investigators found that they were collecting information about certain categories/ codings not listed on the questionnaire (e.g., questions about disappearances, sexual violence other than rape, separation by gender, targeting of the elderly, rebel activity in and/or near the villages). As a result, the coordinators of the ADP passed on such concerns and suggestions to other investigators spread out along the Chad/Sudan border. The question that remains is this: Were the other investigators informed in a timely manner about the additional categories? If not, did the investigators, of their own accord, add additional categories where they saw fit? If only some 
of the investigators added additional categories, then the information collected in new categories would be incomplete. That said, the major categories that the State Department used to make the determination of genocide were included on the questionnaire every investigator used, and thus the latter concern did not have much bearing, if any at all, on the final determination of genocide. Finally, the process of delineating the data on the questionnaires could have been much more detailed (and uniform) had the investigators been directed to write up the most detailed narratives possible, as opposed to delineating the findings, as many did, in an outline format in which they highlighted and, in various cases, succinctly commented on key points.

According to sources within the US State Department, the final determination of genocide was arrived at in a methodical and deliberate manner whereby the evidence gathered during the investigation was compared to the exact wording and concepts delineated in the UNCG. Be that as it may, numerous scholars have called into question the motive(s) behind the determination of genocide. Some have not only questioned these motives but questioned, or attempted to refute, the validity of the determination.

Prior to highlighting some of the many debates surrounding the motives and validity of the determination, this author (one of the twenty-four ADP investigators, and one who believes that the determination of genocide was the correct one to make) wishes to raise some issues already alluded to in this article. Earlier comments quoted here indicate that the Bush administration felt pressed to display its concern over Darfur. For example, as Kostas notes, "U.S. policy in Sudan was already of special interest to the Bush administration, and had an important domestic constituency: the evangelical Christian community. Evangelicals had taken an interest in the plight of black Christians in southern Sudan and there was a growing left-right coalition on Darfur." 29 Furthermore, as Lorne Craner has explained, "the Bush administration was eager to point to its leadership on Sudan policy to demonstrate that they could speak with authority on grave issues of human rights at a time when issues around the treatment of detainees, particularly at Guantánamo and Abu Ghraib, threatened to strip the administration's voice of legitimacy on human rights issues." 30 These comments raise several questions: Was the determination of genocide truly as "dispassionate and clinical" (cum "apolitical") as some within the Bush administration claim? Was there possibly a bias going into the investigation that genocide would be found (or, at the least, was there, as strange as this sounds, an ardent hope that it would be found?), and did that somehow tip the scale in favor of such a determination? And was there already a plan that, if a genocide determination was made, the White House would simply pass the matter onto the UN, thus being able to claim, as it did, that the United States need not do any more than it had already done? At this point, such questions are simply that: questions; however, they do merit further examination and study. It should be duly noted that these questions are raised here not to question the validity of the determination of the genocide but to acknowledge that there may have been certain factors at work that favored a particular determinationthat is, a certain propensity in favor of making such a determination versus not doing so. ${ }^{31}$

A host of other questions also come to mind. In "A Problem from Hell": America and the Age of Genocide, Samantha Power reports that after being elected and while reading about the Clinton administration's failure in Rwanda, George W. Bush "wrote in firm letters in the margin of the memo: "NOT ON MY WATCH."32 Power goes on to 
comment that "While he [George W. Bush] was commander in chief, he was saying, genocide would not recur." 33 While Bush has obviously reneged on the promise he made to himself, it is possible that he may have thought that by declaring genocide (something the Clinton administration failed to do regarding Rwanda-that administration, in fact, as is well known, even went so far as to warn its officials/bureaucrats not to use the so-called g-word), his administration was, at least in part, taking the high road.

Alex de Waal, an expert on the Sudan, has raised two questions about the genocide determination, and his own responses to each of these questions further complicates the issue of the possible motive(s) behind that determination:

Is the U.S. government's determination that the atrocities in Darfur qualify as "genocide" an accurate depiction of the horrors of that war and famine? Or is it the cynical addition of "genocide" to America's armoury of hegemonic interventionismtypically at the expense of the Arabs? The answer is both. The genocide finding is accurate according to the letter of the law. ${ }^{34}$ But it is no help to understanding what is happening in Darfur, or to finding a solution.

And this description merely serves the purposes of a philanthropic alibi to the U.S. projection of power. ${ }^{35}$

In addressing the political nature of the determination of genocide, de Waal asserts that

The 9 September [2004] determination is the first time the Genocide Convention has been used to diagnose genocide (rather than prosecute it).... What does the U.S. determination signify? At one level, it is the outcome of a very specific set of political processes in Washington, D.C., in which interest groups were contending for control over U.S. policy towards Sudan. In this context, the call to set up a State Department inquiry into whether there was genocide in Darfur was a tactical manoeuvre destined to placate the anti-Khartoum lobbies circling around Congress (an unlikely alliance of liberal journalists and human rights advocates, and the religious right), while buying time for those in the State Department committed to pushing a negotiated settlement.... ${ }^{36}$

But at another level, the genocide determination reveals much about the U.S. role in the world today, and the unstated principles on which U.S. power is exercised. Those principles are shared by both the advocates of U.S. global domination and their liberal critics, and are revealed in the commonest narrative around genocide, which takes the form of a salvation fairy tale, with the U.S. playing the role of the savior. ${ }^{37}$

... For six decades, Americans have been dreaming of redeeming that historic fatal tardiness, and dispatching troops in time to save the day. Their failure to do so in Rwanda and Bosnia ten years ago sparked another round of soul searching and led directly to the Kosovo bombing campaign and the Darfur genocide determination. ${ }^{38}$

De Waal's criticism that the 9 September determination was the first time the UNCG had been used to diagnose genocide, rather than to prosecute it, is, to my mind, misplaced. Indeed, it seems to me that using the UNCG for the purpose of diagnosing genocide should, at least when done seriously and conscientiously, be praised rather than criticized. (Furthermore, the findings of the ADP led the United States to refer the matter to the United Nations, and the latter, following its own investigation, referred the matter to the International Criminal Court. As a result, the ICC is now conducting an investigation into the atrocities in Darfur for the express purpose of bringing suspected perpetrators to trial. Thus, in fact, the ADP has contributed to the current effort to bring the perpetrators to trial.) Indeed, why should the UNCG not be used to diagnose genocide? If and when it can serve that purpose, then it should do so. 
Too often scholars, political analysts, activists, politicians, and the media posit guesses (some of them wild) as to whether or not a crisis constitutes genocide, and that is problematic. Is it not better to gather solid data-granted, preferably early on, and certainly much earlier than the United States did vis-à-vis Darfur-prior to making a determination? This is not to say that the international community should wait until a genocide determination is made to act to halt mass killing. Indeed, whenever any threat or actual outbreak of mass killing takes place, then strong, effective measures should be taken to halt it immediately. Surely, however, an accurate determination is preferable to guesswork.

As for de Waal's point that the pressure to establish a State Department investigation was "a tactical manoeuvre destined to placate the anti-Khartoum lobbies circling around Congress...while buying time for those in the State Department committed to pushing a negotiated settlement," a question that comes to mind is, What is the evidence for such an assertion? If, though, even for the sake of argument, one assumes de Waal is correct, then a further question arises: Just how significant is his point? First, it is almost a given that most countries will attempt to negotiate a settlement before resorting to military means. And, generally, this is a good idea. That said, negotiating with actors that are intransigent and not likely to negotiate in good faith is not only a waste of time but unconscionable when large numbers of people are being killed during the negotiation process. As we now know, the ongoing attempt to negotiate with both the GoS and the rebel groups has largely proved fruitless. Furthermore, it quickly became apparent that "talk" by the international community served, once again, as a substitute for action, and at the same time the killing and the dying (as a result of both murder and genocide by attrition) in Darfur continued unabated. That was, and is, unconscionable. It seems that a better target for de Waal's criticisms would have been the incessant talk carried out by the international community, rather than the implementation of the ADP. ${ }^{39}$

Undoubtedly, intervention to halt the killing would have been preferable (at least to some) to the ongoing negotiations that got nowhere but that was not in the cards for the United States, in light of its ongoing "war against terrorism" in Afghanistan and Iraq. That is, it is dubious that the Pentagon would readily-or, for that matter, begrudgingly - have agreed to send troops into another potential quagmire, especially when the armed services were already having difficulty recruiting enough personnel for the war in Iraq. Over and above this fact, the so-called Somalia Factor still haunts many within the US government. ${ }^{40}$ Finally, some prognosticators have also ventured that, in light of the US-Sudanese collaboration on the "war on terror," the Bush Administration would not countenance an intervention that would put such cooperation at risk.

If de Waal is correct that the ADP was used as a ploy to stave off criticism while focusing on negotiations, it is also true that governments are not known for acting in the most altruistic manner possible. It is also a fact that governments act for a multiplicity of motives, some more-and some less-altruistic than others. Also, except in totalitarian states, governments are not monolithic entities, and some branches or departments may address issues and make decisions that are not necessarily shared by, or in accord with, other branches or departments. Aside from all is it so grievous if the ADP was initiated under pressure, and not for the best of reasons? Is that any reason to dismiss an investigation that was handled in a highly professional manner and resulted in a methodologically sound analysis? At the very least, the United States was doing something besides talking. ${ }^{41}$ 
Another possible motive behind the ADP, which de Waal does not take into consideration, was the fact that sanctions had been threatened time and again by the UN but were never carried out, and thus they soon became little more than "paper tigers." This continued to happen even when the United States introduced resolutions aimed at Sudan only to have them watered down by various members of the UN Security Council, purportedly to avoid "upsetting Khartoum." The point is that it is just as likely that the US carried out the ADP, as Craner suggests, ${ }^{42}$ in the hope of moving the international community to action. If so, this could hardly be construed as a questionable or despicable aim.

De Waal is undoubtedly correct that the Darfur crisis did release, as he says, "another round of soul searching." But is that necessarily bad? I would submit that it is not. Would de Waal, one wonders, prefer the opposite reaction?

Granted, some critics of the ADP have inferred that the ADP was largely a cosmetic action-something fairly innocuous in the place of real action. ${ }^{43}$ This is possible. But, then, who would have thought that a finding of genocide would constitute an innocuous action? Certainly not such actors as Natsios and Craner, the two prime movers behind the ADP. Still, the fact is that, sadly, in many ways-and particularly in light of the lack of action by the United States to truly push the international community to halt the killing and death-the assertion that it was largely cosmetic is difficult (if not impossible) to refute. Again, the only saving grace is that the finding of the ADP has led to the ICC's current attempt to bring the perpetrators to trial. Be that as it may, that has done virtually nothing to protect the victims of the GoS and the Janjaweed over the past year and a half.

De Waal's assertion that the United States conducted the investigation in order to enact a "salvation fairy tale" so that it could play "the role of the saviour" is, at least in one sense, so outlandish as to be utterly absurd. ${ }^{44}$ Possibly many at the State Department and some within the executive branch felt that the investigation constituted a kind of salvation affair, but in the long run no one, it seems, including Powell and Bush, could conclude that the United States, in any way whatsoever, played the role of savior-and that is true for the simple but profound reason that the United States did the very minimum it could to prevent the killing and rape of the black Africans of Darfur. The minimum this side of doing nothing, that is.

De Waal sees the determination of genocide as even more problematic than the motive(s) behind the investigation, and this is because, as he puts it, "the fact that the group labelled as genocidaire in this [the Darfur] conflict are 'Arab' is no accident." 45 More specifically, he asserts that

There's no covert masterplan in Washington to brand Arabs genocidal criminals, but rather an aggregation of circumstance that has led to the genocide determination. It has special saliency in the shadow of the U.S. "global war on terror," misdirected into the occupation of Iraq and seen across the Arab and Muslim worlds as a reborn political Orientalism. ${ }^{46}$

After 11 September 2001, the U.S. sees Muslim Arabs as actual or potential terrorists targeting the homeland. After 9 September 2004 ... Arabs (and perhaps all Muslims too) are actual or potential genocidaires, and their targets are Africans. It's sad but predicable that too many Africans will fall for this trap and that the brave efforts of the African Union to build a continental architecture for peace and security will be impaled on an externally constructed divide. ${ }^{47}$

The latter argument is likely to attract considerable debate. One must, at the least, question the validity of his assertion and argument in light of the fact that 
the Bush administration has reached out to the GoS, an Arab-run government, for help in its fight against terrorism. More specifically, in May 2005, the CIA flew Salah Gosh, head of Sudan's National Security and Intelligence Service, to CIA headquarters in Langley to confer with top CIA administrators. At the time, the CIA must have known that Gosh was enmeshed in the Darfur crisis and was likely issuing directives to GoS troops and the Janjaweed. ${ }^{48}$ The point is that to paint the United States with such large swaths of opprobrium is somewhat misdirected-and, some would no doubt claim, sorely so.

It must also be pointed out, however, that the relationship between the United States and Sudan in the so-called war on terror raises the very real issue of just how much pressure the United States is really willing to place on the Sudanese government. Desperate for allies on the anti-terrorism front, the United States is highly unlikely to risk losing out on major assistance in the area of intelligence gathering, especially in an area as "fecund" as Sudan.

Howard Adelman, a philosophy professor who has written extensively about genocide and issues of intervention, is another who vehemently disagrees with the US determination of genocide and has also raised a host of questions regarding the motives of the United States. Among some of the many questions he has raised are these: "What influence did the desire not to repeat American inaction on Rwanda have on characterizing Darfur as genocide?", "What was the influence of the Christian lobby on the resolutions?", and "What was the influence of the immanence [sic] of the 2004 election?" 49

There is no point in repeating the discussion above as to whether the United States had honorable or ulterior motives in carrying out the investigation. As for Adelman's criticism of the determination, he cites all the actors who were and are in disagreement with it (e.g., the United Nations, the European Union, Doctors without Borders) and asserts that the atrocities and other actions constitute, at worst, crimes against humanity. Over-reliance on the UN Commission of Inquiry's findings, however, seem ill advised. ${ }^{50}$

As for Doctors without Borders, Adelman asserts that such a reputable group, whose leader called for an intervention early on during the 1994 Rwandan genocide and whose personnel have been on the ground for extended periods in Darfur, should be duly recognized when it claims that genocide has not been perpetrated in Darfur. But that is dubious advice for numerous reasons. First, Doctors without Borders has never conducted its own investigation to ascertain whether or not the crisis in Darfur constituted genocide. Second, Doctors without Borders did not provide empirical, let alone conclusive, evidence to support its pronouncement. Third, Adelman has a relatively close relationship with the African Union and has previously asserted that he believes calling for an international intervention undermines the will and efforts of that organization. Ultimately, only he can know how his association with the African Union affects his stance on how to categorize the atrocities and deaths in Darfur.

One of the fiercest critics of the determination of genocide by Powell and Bush was (and continues to be) Professor Eric Reeves of Smith College in Northampton, Massachusetts. In fact, Reeves agrees with the determination; his caustic criticism is the result of the lack of action that has followed. In a piece entitled "Secretary of State Colin Powell's Genocide Determination: What It Does, and Doesn't, Mean for Darfur," Reeves asserts that "by arguing in yesterday's testimony before the Senate Foreign Relations Committee that the obligation to 'prevent' genocide entails so very little, Powell has done what his State Department spokesmen have done for months; he has 
made it less likely that the Genocide Convention will ever be used as a tool to serve the primary purpose for which it was created." ${ }^{51}$ Continuing, Reeves argues that

\begin{abstract}
Powell's genocide determination may actually signal the end of the Genocide Convention as a tool of deterrence and prevention. For if a finding of this sort, rendered in light of the most conspicuous evidence of ongoing genocide, prompts no action, then the precedent created during yesterday's Senate testimony by the US Secretary of State is wholly unfortunate.

The insistence that, despite a genocide finding, "no new action is dictated" reflects in part US impotence at the UN, a function in many ways of diplomatic capital expended on the war in Iraq. Indeed, under questioning by Senators on the Foreign Relations Committee, it became painfully clear that the new US draft resolution being circulated at the UN Security Council is not so much a draft as a plea. The purposed resolution is vague, without a clear or explicit threat of sanctions, and establishes no meaningful new benchmarks for Khartoum. ${ }^{52}$

This provides a certain ghastly clarity in the new world of the 21st century: even genocide, even the crime that defined the actions in Rwanda and Eastern Europe during the Holocaust, does not entail any special response or effort of prevention. If this indeed marks the end of any particular obligations under the Genocide Convention, we may legitimately wonder whether the price paid for Powell's determination is not exorbitantly high. ${ }^{53}$
\end{abstract}

Reeves is certainly justified in his disappointment in and criticism of the US assertion that it had done all it could do for the targeted population in Darfur and its subsequent lack of action following the determination. Indeed, once the US government declared that Sudan had committed genocide, the United States, aside from providing hundreds of millions of dollars, did the minimum it could (i.e., referring the matter to the UN Security Council) without totally losing face. Furthermore, its justification that it had done everything it could do was not only disingenuous but a brazen lie. Be that as it may, Reeves's assertion that Powell, and thus the United States, had "made it less likely that the Genocide Convention will ever be used as a tool to serve the primary purpose for which it was created" is, or so it seems, nothing short of hyperbole. Of course, only time will tell if Reeves is correct, but "ever" is a long time. Even if the international community takes another hundred years or more to act in good faith when it comes to genocide and make effective use of the UNCG to prevent or halt genocide, then all will not have been for naught-and it will "prove" that Reeves's statement is, in fact, hyperbole. Nevertheless, one can certainly empathize with his sense of utter disappointment and share his dismay at the disastrous impact that the United States' timid and unconscionable response not only will have on the black Africans of Darfur but is likely to have on the wide range of other groups that will, inevitably, face major human rights violations, including crimes against humanity and genocide, in the near and the distant future.

As for Reeves's criticism of Powell's assertion that "no new action is dictated," Powell, of course, was talking about any action by the United States. Legally, Powell was absolutely correct. Be that as it may, many are bound to find Powell's, and the United States', position morally questionable, at best. Others are likely to counter that preventing and/or halting genocide should be a shared responsibility and not something to be left to a single nation, no matter how powerful. Still, when all is said and done-and not even taking into consideration the possibility of unilateral intervention-Reeves is correct in asserting that the United States could have done far more than it did. 
Reeves is also highly critical of the lack of "teeth" in the resolution that the United States submitted to the UN Security Council. As Reeves puts it, "What is most striking about Powell's testimony concerning the proposed US resolution for the Security Council is its utter lack of enforcement provisions." 54 One can hardly argue with Reeves's grievance, and I see no point in doing so. Again, the "actions" (or lack thereof) following the genocide finding left a lot to be desired, and that is a major understatement. And, in the past year and a half since the declaration, such lack of action is what has caused the greatest consternation among critics of the US government's approach to Darfur.

Finally, Reeves blasts the US government for its tardy response to the ongoing crisis:

Powell...attempt[s] to suggest that the State Department responded in a timely fashion to the threat of genocide. This is not true. Ample evidence was available at the end of 2003, clearly suggesting that genocide was occurring (by December 2003 the nature of the fall offensive by Khartoum and the Janjaweed became fully evident). Human rights reports, alluded to at one point in Powell's testimony, were filled with details suggesting that genocide was unfolding. Certainly by February of 2004, as attacks on the African tribal populations of Darfur again dramatically increased, there was more than enough evidence to justify a genocide investigation. And yet the State Department deployed an investigative team only in July, almost half a year later. This was shamefully belated action-shamefully. ${ }^{55}$

Reeves's criticism is both fair and justified. The investigation could-and shouldhave taken place earlier. A government truly dedicated to genocide prevention would have seen to that. That said, to bring to fruition such an investigation is not within the purview of any single individual within a government, and thus it takes considerable time to move such an idea through the necessary channels. One must also take into account the fact that there was a lot of infighting within the Department of State over Darfur, and it no doubt took a great deal of effort and time to overcome objections to such an investigation. This is not, in any way whatsoever, to condone the tardiness of the investigation, but simply to acknowledge the reality of how governments work. Such a reality underscores the need to establish a strong anti-genocide regime that is buffeted as little as possible by partisan politics and realpolitik. Currently, however, that is solely a goal and dream of genocide scholars and many human rights activistsand, skeptics, of course, might venture that it is little more than a utopian idea. Again, time will tell.

Gérard Prunier, an expert on East Africa, the Horn, Sudan, and the Great Lakes of Africa and the author of Darfur: The Ambiguous Genocide, has also weighed in on the motives of the investigation, the genocide determination, and the aftermath of the latter. With respect to the motive(s) behind the investigation, Prunier seems to suggest that the ever-increasing pressure-from constituents, non-governmental organizations, Congress, and others-for the US government to act may have prompted Bush to support a "genocide investigation" into the Darfur crisis:

On 1 June 2004 the members of Congress who sympathized with the SPLA sent President Bush a list of twenty-three names of Janjaweed supporters, controllers and commanders who were either members of the GOS or closely linked to it. The message was clear: do something about these people. President Bush seemed to have been embarrassed by the implicit demand, all the more because supporters of the antiKhartoum legislation tended to be more "on the left" (in so far as this political category has relevance in US politics) within both parties and within the fairly tight Black 
Caucus. President Bush could not be expected to care too much about "the left," but unfortunately for him there was a core group of anti-Khartoum activists at the opposite end of the political spectrum, from where he drew most of his electoral support. Many fundamentalist Protestant organizations had rallied to the anti-Khartoum lobby activated by Nina Shea. Then by mid-2004 vocal Jewish groups such as the Committee for the Holocaust Memorial [sic] in Washington had joined in the indignant chorus of protests about Darfur. The President thus found himself under pressure from an array of public opinion elements too wide to be ignored during an election year. But since the "realists" in the intelligence community kept insisting that Khartoum was too important to be harshly treated, these contradictory pressures led the White House to compromise on all fronts-supporting the Naivasha negotiations, [and] not putting too much practical pressure on Khartoum but nevertheless passing legislation which could be used as a sword of Damocles in case of non-compliance... ${ }^{56}$

Continuing, Prunier drops a bombshell of sorts, especially if the assertion is true: "This author was assured that Secretary of State Colin Powell had practically been ordered to use the term "genocide" during [his] high profile 9 September 2004 testimony to the Senate Committee on Foreign Relations but that he [had] also been advised in the same breath that this did not oblige the United States to undertake any sort of drastic action, such as a military intervention." ${ }^{57}$ Prunier's source for the latter assertion is a "confidential interview with a high-ranking member of the US administration, [in] Washington [in] October 2004."58 It is certainly possible, of course, that Powell had received a "push" in that direction. Be that as it may, there are three sticking points in the statement. First, it comes from an unidentified source and cannot readily be followed up. That, of course, does not mean it is not true, but it does complicate matters. Second, Prunier uses the words "practically been ordered." So Powell, ostensibly, was not ordered but was strongly encouraged, pressured, prodded, or goaded to do so. Third, Prunier uses the word "advised." Being "advised," of course, is not the same as being told, directed, or ordered to do something. The questions that arise from such wording are many, including but not limited to the following: Was Powell, in fact, "practically ordered" to use the word "genocide," and did he cave in to the pressure or act the part of the "good soldier"? Or was the analysis of the data collected by the ADT persuasive "enough" that Powell felt comfortable using the word "genocide" of his own accord? Or was the analysis of the data persuasive enough that Powell did not feel guilty using the word "genocide" when all but ordered to do so? The same sorts of questions, of course, are germane to his statement about the United States' not being obligated to do any more than it already had done vis-à-vis Darfur.

Prunier concludes by asserting that "President Bush tried to be all things to all men on the Sudan/Darfur question. Never mind that the result was predictably confused. What mattered was that attractive promises could be handed around without any sort of firm commitment being made. Predictably, the interest level of US diplomacy on the Sudan question dropped sharply as soon as President Bush was reelected." 59 Prunier is certainly correct with respect to his comment about a lack of "firm commitment" being made in the aftermath of the determination. As for US diplomatic efforts vis-à-vis Darfur, they have actually waxed and waned time and again over the course of the past year and a half. There have been spikes of interest (most recently in pushing for the deployment of UN troops and NATO involvement in Darfur), but there have also been mixed messages issued by Bush's underlings in the State Department (e.g., as to whether the situation in Darfur still constitutes genocide and whether there is a need to push for tough sanctions on Khartoum and/or prod the 
UN to undertake an intervention). Ultimately, Prunier is correct in suggesting that "talk" over action has been the modus operandi of the Bush administration's approach to protecting the black Africans of Darfur.

\section{Ramifications of the ADP}

The development and implementation of the ADP, aside from the determination based on the data collected by its team, has numerous ramifications. So too, of course, does the genocide determination by the US government. As one might surmise, some are positive and some are negative.

First, the development and implementation of the ADP set a precedent of sorts in terms of the way in which an individual nation can develop and conduct an investigation for the express purpose of attempting to ascertain whether genocide is being perpetrated in some part of the world. Indeed, it proves that it can be done fairly quickly, efficiently, and effectively and relatively inexpensively. That, in itself, is significant, for far too often, in the past, individual nations, the media, human-rights activists, and the international community have relied more on guesswork and piecemeal information seeping in from different sources than on carefully collected and analyzed data to ascertain the nature of a violent conflict.

Second, the precedent has now been established for an individual nation to conduct an investigation into atrocities while they are being perpetrated for the express purpose of ascertaining whether genocide has been perpetrated or not. While this may appear to be of little note, it is nothing of the sort. If nothing else-and this is significant-there is no excuse for nations with sufficient financial wherewithal to fail to conduct such investigations when it appears that a situation may be spiraling toward crimes against humanity or genocide. In other words, a new bar has been set in making a genocide determination. Now it is up to citizens, human-rights activists, NGOs, genocide scholars, and others to insist on such investigations.

Third, the ADP has provided a solid model for one essential component of an antigenocide regime. Such investigations should become an integral part of any anti-genocide regime, and, thanks to the $\mathrm{ADP}$, this is not a component that will need to be developed from scratch. Given that the ADP was not perfect (but what is?), developers of future investigations can learn from both the strengths and weaknesses of the ADP.

As for the genocide determination, a precedent has been set in which one sovereign nation (the United States) has accused another sovereign nation (Sudan) of committing genocide while the atrocities were still ongoing. This, in itself, was a historic event and thus significant. That is, the determination broke, if you will, a certain taboo against individual nations' making such an accusation when not only justified in doing so but, if signatories to the UNCG, morally obligated to do so.

Be that as it may-and ironically and sadly_there is also the danger, as numerous scholars and commentators have asserted, that, in the end, the genocide determination by the United States could prove counterproductive. More specifically, the fact that the determination was made and then the matter was simply and solely referred to the UN Security Council does not bode well for those in favor of a proactive stance against genocide. Indeed, the fact that the determination did not result in any concrete action by the United States to attempt to halt the ongoing genocide may, in the short run (but even here we are talking about throwing into the lurch precious and fragile lives of untold numbers of people)_if not in the long run-result in minimizing the "weight" and significance of such a finding. That is, other nations and international bodies may 
now perceive such determinations simply a matter of course and of no great consequence.

As the cliché goes, only time will tell. That said, de Waal makes the interesting point that "although Colin Powell insisted the U.S. policy towards Sudan would remain unchanged - thereby seeming to defeat the purpose of making the determination in the first place - there is no doubt that declaring genocide creates legal and political space for intervention." ${ }^{00}$ It is still possible, of course, for a military intervention to take place in Darfur. While most would agree that if an intervention is eventually carried out it will have been horrifically late in coming, it is crucial to recognize and appreciate the fact that some 2 million displaced persons are still at the mercy of the GoS and the Janjaweed and are in need of all the help they can get in staving off even more terror and mayhem. And if an intervention does take place, then the genocide determination by the US may well have served the important purpose, at least in part, of having "created the legal and political [and one might add, moral] space" for doing so.

\section{Conclusion}

Aside from continuing to provide humanitarian aid, which was not, of course, inconsequential, the only other major action that the United States undertook following its determination of genocide was to refer the matter to the UN Security Council. In doing so, it called for a more comprehensive study of the Darfur crisis. At the time, many scholars and activists raised the issue of whether another study was really needed, especially in light of the fact that no one-other than Khartoum, perhaps-doubted that grave crimes against humanity had been perpetrated against the black Africans in Darfur and that they continued to perish in huge numbers as a result of the actions of the GoS and Janjaweed.

A question that has been asked by many, though it was largely rhetorical, was, Did the United States actually do all it could? The answer was, and continues to be, an emphatic "No!" Among some of the many options that the United States could have pursued but chose not to-no doubt for reasons of realpolitik-were to push implacably for a multilateral effort to establish a no-fly zone over Darfur, or do it alone; to apply unrelenting pressure on the UN Security Council to establish a strong, mandate under chapter VII of the UN Charter that would allow the AU troops (and others) to truly protect the black Africans at risk; to apply equally unrelenting pressure on the African Union to allow UN troops to join the AU forces in Darfur; to provide the AU troops and recruits with top-notch training prior to their deployment to Darfur; to provide the AU with ample military materiel and equipment, along with a guarantee of fuel and personnel to service that equipment, such as four-wheel vehicles, planes, and so on, instead of providing dribbles of military support; and to serve notice on Khartoum that if it continued to interfere with or outright block humanitarian aid from reaching the IDP camps, the repercussions would be serious-and then act on such notice in a timely and effective manner. Noticeably absent from this list is the possibility of the United States' actually sending its own troops to Darfur, whether as a multilateral or a unilateral effort, supported or not supported by the UN Security Council. Again, as discussed above, this was never, at least as far as the Bush administration was concerned, a real option. The point is, however, that there is plenty that the United States could have done-and still should do-but it has not. And that is nothing short of shameful. 


\section{Acknowledgments}

I sincerely thank Dr. Herb Hirsch, Dr. Alex Alvarez, and Dr. Eric Markusen for their solid critiques of this article and for their helpful suggestions. I also sincerely thank Ms. Debb Bodkin for her unique insights into the UN's Commission of Inquiry on Darfur.

\section{Notes}

1. United Nations, "Sudan: World's Worst Humanitarian Crisis" (press release, 22 March 2004).

2. Stephen A. Kostas, "Making the Determination of Genocide in Darfur," in Genocide in Darfur: Investigating the Atrocities in the Sudan, ed. Samuel Totten and Eric Markusen (New York: Routledge, forthcoming).

3. Ibid., 4. For an informative and detailed discussion as to what prompted the State Department to investigate the internal conflict in Sudan, see Kostas, ibid.

4. It is also important to note that "the U.S. was exasperated by international inertia, and Craner believed that if the U.S. could authoritatively call it [the killings and deaths in Darfur] genocide, it might mobilize European governments to take a more aggressive approach." Ibid., 8

5. US Department of State, Documenting Atrocities in Darfur (Washington, DC: Bureau of Democracy, Human Rights and Labor and Bureau off Intelligence and Research, 2004), 2.

6. The questionnaire was used to conduct the semi-structured interviews. For a detailed discussion of the methodology used by the ADT, see Jonathan Howard, "Survey Methodology and the Darfur Genocide," in Genocide in Darfur: Investigating the Atrocities in the Sudan, ed. Samuel Totten and Eric Markusen (New York: Routledge, forthcoming).

7. In regard to the findings, the State Department issued the following caveats: "Several characteristics of the survey must be underscored. First, accounts of atrocities may be dated, depending on when the individual refugee fled his or her village. Second, the data may actually undercount the extent of atrocities because mass attacks often leave few survivors. Third, most respondents come from villages within 50 miles of the border in Western Darfur and Northern Darfur States. Fourth, it is very likely that rapes are underreported because of the social stigma attached to acknowledging such violations of female members of one's family.

"The results are broadly representative of Darfurian refugees in Chad but may not be representative of internally displaced persons still in Darfur because they were not included in the sample. A margin of error for this sample cannot be calculated because of the lack of accurate demographic information about the refugee camps and settlements. The methodology was designed to achieve as broadly representative a sample as was feasible under the prevailing conditions....

"The field data for the 1,136 interviews were compiled using a standardized data entry process that involved the collection and coding of detailed information from each refugee respondent's set of answers. The researchers then used a statistical program to aggregate the data and analyze the results." US State Department, Documenting Atrocities, 7-8.

8. Ibid., 3 .

9. Ibid., 1. "Reported atrocities were included in the data set only if the respondent directly witnessed the event. For the purpose of this study [Documenting Atrocities in Darfur], a respondent is considered to have 'directly witnessed' an atrocity if she or he was an eyewitness to the event, visually confirmed the death of victims, or, in cases of rape, was directly told about the atrocity by the victim. Hearsay accounts were excluded from the data set." Ibid.

10. Ibid., 4.

11. Ibid.

12. Kostas, "Making the Determination," 13. A key question that arises is whether political appointees are truly capable of being "dispassionate and clinical" when making such a 
judgment. Furthermore, can any decision made by governmental officials or entities truly be considered "pure"? That is, are not all decisions political in one way or another?

13. Ibid., 14.

14. US State Department, Documenting Atrocities, 1.

15. Ibid.

16. Quoted in ibid., 15.

17. Ibid.

18. Ibid.

19. Colin Powell, "The Crisis in Darfur" (written remarks before the Senate Foreign Relations Committee, 9 September 2004), http://www.state.gov/secretary/former/powell/remarks/ 36032.htm (accessed 21 April 2006), 4.

20. Ibid., 2.

21. Ibid.

22. Ibid., 3.

23. Convention on Prevention and Punishment of the Crime of Genocide, 9 December 1948, 78 U.N.T.S. 277, http://www.unhchr.ch/html/menu3/b/p_genoci.htm (accessed 21 April 2006).

24. Ibid., 4.

25. Ibid., 5 (emphasis added).

26. Howard, "Survey Methodology," n. pag.

27. Ibid., n. pag.

28. For a discussion of this matter, see US State Department, Documenting Atrocities.

29. Kostas, "Making the Determination," n. pag.

30. Quoted in ibid., 7.

31. While State Department officials were conferring and coming to a decision as to whether the atrocities in Darfur constituted crimes against humanity or genocide, rumors leaked that the final decision could "go either way." This suggests, if the rumors were correct, that the determination of genocide may not have been a foregone conclusion. It also suggests that State Department officials, including Colin Powell, were determined to make the most accurate determination they possibly could.

32. Samantha Power, "A Problem from Hell": America and the Age of Genocide (New York: Basic Books, 2002), 511.

33. Ibid.

34. Speaking of the atrocities committed by the GoS and the Janjaweed, de Waal asserts that "they have killed, burned, raped and starved their way across the central belt of Darfur. In doing so, they have killed thousands of people and deliberately starved thousands more. They have also managed to stop a running insurgency that was rapidly seizing control of the entire region." Alex de Waal, "What Does Adding the 'Genocide' Label to the Darfur Crisis Really Mean?” Index on Censorship, 2 February 2005, www.indexonline.org/en/ news/articles/2005/1/international-true-meanings-and-consequences.shtml (accessed 26 April 2006), para. 9. He also asserts that "Powell is correct in law. According to the facts as known and the law as laid down in the 1948 Genocide Convention, the killings, displacement and rape in Darfur are rightly characterised as 'genocide.' But his finding has significant political implications." Ibid., para. 13. Elsewhere, de Waal has asserted that "famine in Sudan is a crime, and has been a crime for the last 20 years, and the form of genocide that we are seeing in Darfur is, I would argue, a famine crime." Quoted in "The Crisis in Darfur with Jennifer Leaning, Eric Reeves, Alex de Waal, and William Schulz," John F. Kennedy Library and Foundation, 9 December 2004, www.jfklibrary.org/ forum_darfur.html (accessed 10 March 2006), 5.

35. De Waal, ibid., para. 2.

36. Ibid., para. 30 .

37. Ibid., para. 33.

38. Ibid., para. 35 .

39. Some have also argued that the United States' initiation of the ADP was a cynical ploy by the Bush administration to "try to have it both ways"; that is, it allowed the Bush 
administration to assert that it was attempting to defend and protect human rights in Darfur while also allowing it, in the end-especially by not pushing for an intervention-to attempt to solidify its relationship with the GoS. See Prunier, Darfur, 140-41; Eric Reeves, "Secretary of State Colin Powell's Genocide Determination: What It Does, and Doesn't Mean for Darfur" (10 September 10 2004), http://www.sudanreeves.org/modules.php? $\mathrm{op}=$ modload\&name $=$ Sections $\&$ file $=$ index\&req $=$ viewarticle $\&$ artid $=214 \&$ page $=1$ (accessed 26 April 2006), paras. 17-19.

40. The "Somalia Factor" is the legacy of the October 1993 disaster in which US troops attempting to capture top advisors to Mohammed Farah Aideed were attacked by Somali militia and eighteen US soldiers were killed and seventy-three wounded. A Black Hawk helicopter pilot was also kidnapped, and a dead US soldier was dragged through the streets of Mogadishu.

41. I am not so naïve as to think or believe that the investigation might not have been used as a way to show concern that was not all that costly in terms of financial, political, or human capital (meaning lives lost), and thus used in place of calling for-if not leading-a major intervention to halt the killing. That is another issue, and one that needs to be addressed. If the latter is true, then the initiation of the ADP certainly was a problematic, if not a sordid, affair.

42. See Kostas, "Making the Determination."

43. Including Gerald Caplan, Eric Reeves, and Gérard Prunier.

44. De Waal, "What Does Adding," para. 35.

45. Ibid., para. 45.

46. Ibid., para. 41

47. Ibid., para. 42.

48. Tellingly, Gosh reportedly is the number-two person on the list forwarded by the United Nations to the ICC of those who are suspected of having a hand in the killings in Darfur.

49. Howard Adelman, "Reading History Backwards: Rwanda and Darfur" (abstract of a talk given at the conference of the International Association of Genocide Scholars, Boca Raton, FL, 4-7 June 2005), 1. For a discussion of these and related questions (e.g., What is the evidence for genocide in Darfur? Why have other states not fallen into line with the United States in characterizing Darfur as genocide? What impact did the characterization of the crisis in Darfur as genocide have on the effort to get the Security Council to endorse sanctions against Sudan?), see ibid.

50. Debb Bodkin, a police officer based in Canada and the only person who served as an investigator for both the $\mathrm{ADP}$ and the $\mathrm{COI}$, told me that the data collected by the COI were unsystematic and less focused than the ADP's. More specifically, in recent correspondence, Bodkin commented as follows: "During our briefing [about the COI] in Geneva, we were given no format or indication as to how the investigation and interviews were to be conducted. As a result every investigator conducted his/her investigation and interviews in whatever fashion he/she preferred. I cannot believe that with the vast difference in expertise of each investigator there would be any semblance of consistency in regard to the gathering of evidence... The UN investigation did not have any laid out parameters whatsoever and as a result an untrained interviewer could easily ask questions in a manner that would elicit whatever response the interview hoped to obtain.... [Also,] each investigator was open to choose who they interviewed and how.... As far as the soundness of the COI, when I compare it to any of the sexual assault or homicide investigations which I was part of during my police service in Waterloo, Ontario, it would not [have gone forward] due to the low probability of a conviction, mainly because of the fact that the investigators did not meet the required adequacy standards to be conducting interviews and did not have the knowledge, skills or ability to be doing so..." Debb Bodkin, e-mail message to author, 15 April 2006.

Furthermore, Bodkin asserts that while the COI team was in Geneva, prior to entering the field, Antonio Cassese, who oversaw the COI, implied that the COI would not result in a finding of genocide. More specifically, Bodkin, in recent correspondence, conveyed the 
following: "Commissioner Antonio Cassese, who had traveled to Khartoum and some parts of Darfur for a few days and had conducted some interviews, stated that he felt that we would find that there were two elements of genocide missing: (a) target group (victims are from mixed tribes) and (b) mens rea (intent). He talked for a while and my personal opinion was that he was telling us that the outcome of the investigation would show that it was not genocide which was occurring. He did not specify how long he had visited nor how many interviews he had conducted but I don't believe either were extensive. I felt it was very inappropriate for him to plant this opinion in the investigators' minds prior to starting the investigation and other investigators felt uncomfortable about it as well... The female Commissioner [Ms. Hina Jilani from Pakistan] stated: 'Go with an open mind.' During the briefing I got the distinct impression that there was some tension between Commissioner Cassese and Commissioner Jilani as their comments often conflicted with one another and he was expressing what he thought our findings would be whereas she always made comments about us doing our job open-mindedly." Ibid.

Lending further credence to the claim that the UN's Commission of Inquiry's findings are, at best, problematic is Gérard Prunier's cogent observation that "the Report of the UN Commission of Inquiry on the Darfur Violence was the latest but perhaps not only the final example of the world body ... acting ... in a ... show of egregious disingenuousness. The report documented violations of international human rights by "people who might have acted with genocidal intentions'; yet the situation was not genocide..." Gérard Prunier, Darfur: The Ambiguous Genocide (Ithaca, NY: Cornell University Press, 2005), 143.

51. Reeves, 'Secretary of State,' para. 1.

52. Ibid., paras. $3-4$.

53. Ibid., para. 7. Reeves's criticism does not stop there. Continuing, he states that "despite his finding of genocide on the part of Khartoum, Powell preemptively pardons the regime by saying 'we are not trying to punish them.' But shouldn't genocidaires be punished?

Shouldn't there be, as Powell explicitly suggests elsewhere, be an international tribunal to punish the crimes of genocide in Darfur and those guilty of this monstrous crime?... How can Powell simultaneously find the regime guilty of genocide, but then declare that 'we are not trying to punish the Sudanese government' and indeed we may have 'a mutual interest with the Sudanese government'?” Ibid,, para. 17. Actually, Powell's words could be understood in various ways (and thus could be misconstrued). Possibly he was "pardoning" the regime, but that seems dubious. At worst, Powell seemed to be apologizing for the genocide finding while also stating that the US wanted to maintain relations, even if shaky, with Sudan. Then again Powell may simply have misspoken when he used the words "not trying to punish Sudan." Or, possibly, Powell was trying to send a distinct message: Khartoum had better rein in its troops and the Janjaweed if it did not want the United States to come down hard on Sudan. Of course, in retrospect, we now know that if the latter were the actual meaning of the words, they were idle for, again, the United States has done little to nothing since September 2004 to halt the killing and death in Darfur.

54. Ibid., para. 29.

55. Ibid., para. 27.

56. Prunier, Darfur, 139-40.

57. Ibid., 140.

58. Ibid., 191.

59. Ibid., 140.

60. De Waal, "What Does Adding," para. 31. De Waal perceives this as a negative, playing into the hands of the US "hegemonic" push across the globe. 


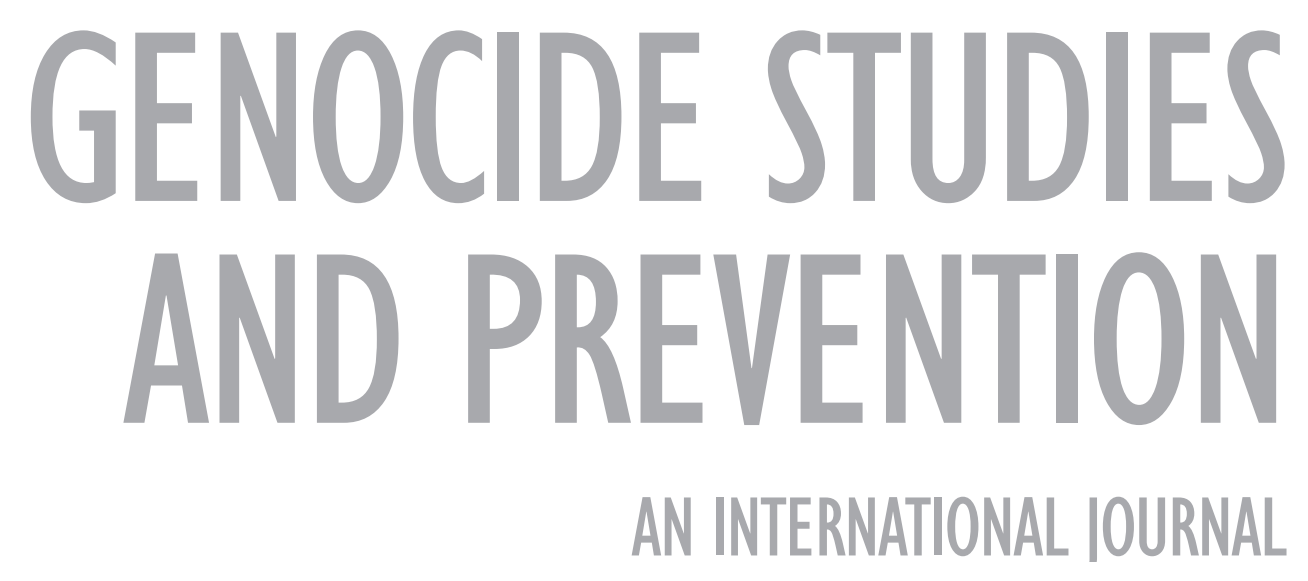

